\title{
Analgesics use for kidney failure *
}

\section{Uso de analgésicos em pacientes com insuficiência renal}

Rioko Kimiko Sakata ${ }^{1}$, Marcelo Henrique Gomes Nunes ${ }^{1}$

${ }^{*}$ Received from Federal University of São Paulo, São Paulo, SP, Brazil.

\section{ABSTRACT}

BACKGROUND AND OBJECTIVES: The use of drugs to treat renal failure has particularities due to pharmacokinetic changes present in such population. This study aimed at supplying subsidies for a rational choice of analgesics to be used in patients with renal failure.

CONTENTS: Information is provided about pain prevalence and etiology in renal failure patients. In addition, the use of antiinflammatory drugs, opioid analgesics and adjuvant drugs for pain management is addressed.

CONCLUSION: Adjusting pharmacological therapy to renal function impairment may provide effective treatment with less adverse effects.

Keywords: Analgesics, Pain management, Renal failure.

\section{RESUMO}

JUSTIFICATIVA E OBJETIVOS: $\mathrm{O}$ uso de fármacos para o tratamento da dor em pacientes com insuficiência renal apresenta particularidades devido às alteraçôes farmacocinéticas presentes nessa população. O objetivo deste estudo foi fornecer subsídios para uma escolha racional dos analgésicos a serem utilizados em pacientes com função renal deficiente.

CONTEÚDO: São fornecidas informaçôes sobre prevalência e etiologia da dor em pacientes com insuficiência renal. Além disso, aborda-se a utilizaçáo de anti-inflamatórios, analgésicos opioides e fármacos adjuvantes para o tratamento da dor.

CONCLUSÃO: $\mathrm{O}$ ajuste da terapêutica farmacológica ao comprometimento da função renal é capaz de prover um tratamento eficaz e com menos efeitos adversos.

Descritores: Analgésicos, Insuficiência renal, Manuseio da dor.

1. Federal University of São Paulo, São Paulo, SP, Brazil.

Submitted in April 08, 2014.

Accepted for publication in August 15, 2014.

Conflict of interests: none.

Correspondence to:

Rioko Kimiko Sakata

Rua Três de Maio 61/51 - Vila Clementino

04044-020 São Paulo, SP, Brasil.

E-mail: riokoks.dcir@epm.br

(c) Sociedade Brasileira para o Estudo da Dor

\section{INTRODUCTION}

Chronic renal failure (CRF) is a common clinical condition followed by several associated diseases ${ }^{1}$. Due to increased survival with the advent of renal replacement therapy and renal transplantations, CRF patients are increasingly submitted to surgical procedures, with the need for effective analgesic therapy in the postoperative period. They are also submitted to several procedures inducing acute pain, such as frequent punctures for dialysis.

Moreover, CRF patients are subject to chronic painful syndromes of different etiologies ${ }^{2}$. In addition to musculoskeletal and degenerative disorders, consequence or not of the kidney disease, this is a population with increased incidence of peripheral vascular ischemic disease and peripheral neuropathies.

This study aimed at reviewing pain prevalence in patients with renal failure stressing etiologies, and at discussing aspects about drugs to its management.

\section{RENAL FAILURE AND PAIN}

In a study, authors have observed the prevalence of manifestations in patients chronically submitted to hemodialysis. Authors have emphasized that musculoskeletal pain complaints were reported by $54 \%$ of patients of that study, something which so far had never been documented ${ }^{3}$. Cramps were observed in $43 \%$, headache in $19 \%$ and chest pain in $10 \%$.

Pain epidemiological characteristics in chronic renal failure patients are poorly known. Most data are from studies on the quality of life or associated symptoms in patients chronically submitted to hemodialysis ${ }^{4-7}$.

In a population of chronic renal patients submitted to hemodialysis, there were pain complaints of different etiologies ${ }^{2}$. Musculoskeletal pain was the most common cause. A small percentage has complained of pain induced by chronic dialytic treatment, such as those triggered by cramps, headache and caused by fistula puncture. Musculoskeletal pain was observed in $63.1 \%$ of patients, being osteoarthritis in $19.4 \%$, undiagnosed pain in $18.4 \%$, inflammatory arthritis in $6.8 \%$, fracture in $9.7 \%$, renal osteodystrophy in $4.9 \%$ and discitis/ osteomyelitis in $1.9 \%$. Dialysis-induced pain was present in $13.6 \%$ of patients, peripheral polyneuropathy in $12.6 \%$, associated to peripheral vascular disease in $9.7 \%$ and carpal tunnel syndrome in $1.9 \%$. Other causes of pain, corresponding to $18.4 \%$ of patients were: trauma, polycystic renal dis- 
ease, cancer and calciphylaxis.

In a different study, authors have evaluated pain complaints of chronic renal patients admitted to nephrological units. Fifty three percent of patients have reported more than one cause for their pain ${ }^{8}$. Reasons were: surgical trauma (43.3\%), peripheral vascular disease $(32.1 \%)$, dialysis-related pain (26.4\%), peripheral neuropathy (18.9\%), osteoarthritis $(9.4 \%)$, inflammatory arthritis $(9.4 \%)$, cancer $(9.4 \%)$, renal osteodystrophy $(7.5 \%)$, gout $(5.7 \%)$, calciphylaxis $(3.8 \%)$, osteomyelitis (1.9\%), osteoporotic fracture (1.9\%) and polycystic renal disease $(1.9 \%)$.

Pain management is inadequate for a significant number of renal failure patients. Several factors may be pointed as responsible for such. Pain is not recognized as a major problem for chronic renal patients. In addition, pharmacokinetic changes and pharmacological interactions are very frequent in this population, making difficult or inhibiting management.

\section{THERAPIES}

\section{Anti-inflammatory drugs, dipyrone and paracetamol}

Anti-inflammatory drugs

Non-steroid anti-inflammatory drugs (NSAIDs) are used in the general population to treat mild to moderate pain. These agents block prostaglandins synthesis through the inhibition of cyclooxygenase enzymes (COX). COX type 1 (COX-1) is called constitutive, being expressed in most tissues; COX type 2 (COX-2) is primarily induced, being mostly present in inflamed tissues ${ }^{9,10}$.

NSAIDs may increase the risk of bleeding in patients with uremia, for their synergistic effects on platelet aggregation inhibition ${ }^{11}$.

Renal prostaglandins synthesis inhibition is responsible for fluid retention, systemic hypertension and electrolytic disorders observed with the use of NSAIDs. There is edema in $3-5 \%$ of chronic anti-inflammatory users ${ }^{12}$. In hypertensive patients, it was observed increase of approximately $5 \mathrm{mmHg}$ in blood pressure ${ }^{13}$. Rennin release inhibition by renal prostaglandins, with less sodium supply to distal tubules is responsible for hypercalcemia and other electrolytic disorders observed with the use of NSAIDs. Hypercalcemia is pronounced especially in patients with uncompensated diabetes, heart failure, multiple myeloma, and users of angiotensin-converting enzyme, betablockers and potassium-sparing diuretics ${ }^{11}$.

NSAIDs also induce reversible decrease in glomerular filtration rate (GFR). Residual renal function in patients under renal replacement therapy is critical for the well-being of such patients. It is associated to longer survival, less weight gain between sessions and better solute clearance ${ }^{11}$.

Indomethacin is the NSAID decreasing GFR the most ${ }^{14}$. Naproxen, diclofenac, piroxicam and ibuprofen have intermediate effect. Aspirin is the NSAID interfering the least with GFR $^{15}$. Notwithstanding COX-2 induction being more often observed in inflammation sites, it is constitutively expressed in the kidney and has important function in the maintenance of renal hemodynamics. There is benefit with the use of se- lective COX-2 inhibitors in patients with increased risk of hemorrhages. However, such drugs have renal effects similar to non-selective inhibitors, being contraindicated for renal failure patients ${ }^{11}$.

\section{Dipyrone and paracetamol}

These are drugs with analgesic and antipyretic action and little or no anti-inflammatory activity. They have weak inhibitory activity on COX-1 and COX-2 ${ }^{16,17}$.

Dipyrone action mechanism is still controversial. Experimental trials have shown inhibition of adenylate cyclase activation by hyperalgesic substances and direct blockade of calcium entrance in nociceptors ${ }^{18}$. Other authors have reported analgesic properties from the action of dipyrone metabolites on prostaglandins synthesis in the central nervous system (bulbus and periaqueductal gray matter ${ }^{19}$.

Dipyrone has high clinical efficacy, low cost, broad availability and safety margin, especially for renal patients?

Antipyretic action mechanism proposed for paracetamol associates the drug to the inhibition of prostaglandins synthesis in the hypothalamus ${ }^{9}$. As analgesic, the drug has to be able to activate inhibitory serotoninergic antinociceptive pathways ${ }^{20}$. Paracetamol is effective in doses up to $90 \mathrm{mg} \cdot \mathrm{kg}^{-1}$ or 4 g.day ${ }^{-1}$. There is hepatotoxic activity when administered in high doses (150 mg. $\mathrm{kg}^{-1}$, or 5-30g). Liver injury occurs by depletion of glutathione stocks, leading to the building up of toxic metabolites in the hepatocyte, and to histopathological findings of centrolobular necrosis ${ }^{21}$. There are reports of kidney toxicity after administration of glutathione to treat liver toxicity. Glutathione may provide the formation of nephrotoxic compounds which culminate with the activation of caspases and liposomal enzymes, starting apoptosis and renal dysfunction ${ }^{22}$.

Paracetamol is the analgesic of choice for elderly patients or those with impaired renal function ${ }^{23}$. In therapeutic doses, renal toxicity is rare ${ }^{10}$. There is no need for dose adjustment in renal failure, but some authors recommend increasing dose intervals from 6 to 8 hours when GFR is below $10 \mathrm{~mL} \cdot \mathrm{min}^{-1} 24$.

\section{Opioid analgesics}

Tramadol

This is a drug with agonist activity on opioid receptors $(\mu)$, and inhibitory action on serotonin and norepinephrine reuptake, increasing such inhibitory neurotransmitters in the medullary synapse. It is metabolized in the liver, being $30 \%$ of the drug and $60 \%$ as active metabolites, excreted by the urine $^{25}$. Although forming active metabolites, the risk of toxicity is low ${ }^{26}$.

Due to its action mechanisms, it is an effective drug to treat nociceptive and neuropathic pain, with the advantage of promoting less sedation and ventilatory depression as compared to agonist opioids. Nausea is a common adverse effect. In patients under drugs decreasing convulsive threshold, such as selective serotonin reuptake inhibitor antidepressants, it may trigger epileptic crises, in addition to serotoninergic syndrome ${ }^{27}$.

In advanced CRF, elimination half-life may double, being necessary to decrease the dose $-200 \mathrm{mg}$.day ${ }^{-1}$ if GFR is below 
$30 \mathrm{~mL} \cdot \mathrm{min}^{-1}$, and $100 \mathrm{mg}$.day ${ }^{-1}$ if GFR is below $10 \mathrm{~mL} \cdot \mathrm{min}^{-1} 25$. It is dialyzable and safe for patients with dialytic CRF ${ }^{26}$. Since it is easily removed by hemodialysis, it should be administered after the sessions ${ }^{28}$.

\section{Codeine}

This is a morphine derivative with moderate analgesic activity. Its liver metabolizing gives origin to codein-6-glucoronide $(80 \%)$, and $5 \%$ is demethylated to morphine, which forms active metabolites which depend on renal excretion ${ }^{29,30}$.

Analgesic activity of this drug comes from the action of its metabolites on $\mu$ opioid receptors ${ }^{30,31}$.

In patients with CRF, renal clearance of codeine and its metabolites is significantly decreased, with higher risk of severe adverse effects, such as sedation, ventilatory depression and hypotension ${ }^{32}$. This way, care is needed when prescribing codeine to patients with renal failure ${ }^{31}$. Due to its high distribution volume and molecular weight, it is not easily removed by hemodialysis and should be avoided in patients needing renal replacement therapy ${ }^{31-33}$. Risk of toxicity is uncertain. It is dialyzable, but should be avoided, if possible, for patients with dialytic $\mathrm{CRF}^{26}$.

\section{Oxicodone}

This is a semi-synthetic opioid with twice the analgesic potency of morphine. Its onset of action is one hour after oral administration and duration is $12 \mathrm{~h}$ for the scheduled release formulation ${ }^{34}$.

It is metabolized in the liver and the drug depends on the kidney for the excretion of active metabolites and part of the original compound $\mathrm{d}^{35}$. In the presence of renal failure there may be drugs build up and adverse effects as a consequence of the action of metabolites on the central nervous system ${ }^{31}$. Oxycodone should be avoided if GFL is below $60 \mathrm{~mL} \cdot \mathrm{min}^{-1} 34$. For being hydrosoluble, it is dialyzable. There are, however reports of lethargy and ventilatory depression in dialytic patients under multiple oxycodone doses per day ${ }^{36}$.

Toxicity risk is uncertain. It is not known whether it is dialyzable and whether it is safe for dialytic CRF patients ${ }^{26}$.

\section{Morphine}

This is the most widely studied opioid for renal failure. It is metabolized in the liver into morphine-3-glucoronide (M3G) and morphine-6-glucoronide (M6G), in addition to the formation of diamorphine and normorphine. M6G is approximately 10 times more potent than its original compound. All metabolites and $10 \%$ of the original drug depend on renal excretion $^{37}$.

There is M6G build up in renal failure, causing ventilatory and CNS depression. Since its blood-brain barrier crossing is slow, adverse effects of M6G may be long-lasting, persisting even after drug withdrawal or dialytic treatment, in spite of good drug and its metabolites clearance by dialysis ${ }^{38}$.

Analgesic and adverse effects of this drug are correlated to morphine and M6G plasma concentrations. This way, there is the need for decreasing the dose in $25 \%, 50 \%$ and $75 \%$ when there is CRF in stages 3, 4 and 5, respectively ${ }^{37}$. When safer opioids are available, morphine should be avoided in patients with renal failure ${ }^{39}$.

Recommended dose for patients with GFR above $50 \mathrm{~mL} / \mathrm{min}$ is $100 \%$; for GFR $10-50 \mathrm{~mL} / \mathrm{min}$ it is $75 \%$ and for GFR below $10 \mathrm{~mL} / \mathrm{min}$ it is $50 \%{ }^{40}$.

Toxicity risk is uncertain. It is dialyzable, but should be avoided, if possible, for patients with dialytic CRF ${ }^{26}$.

\section{Meperidine}

This is a synthetic opioid with shorter duration analgesia as compared to remaining commonly used drugs. It has approximately $1 / 10$ of morphine potency. Its active metabolite, normeperidine, has long elimination half-life (15-40h) and depends on renal excretion. There may be build up of this metabolite in renal failure patients with adverse effects such as shivering, myoclonus, seizure and delirium. So, it should not be used in patients with renal failure ${ }^{41}$. Remember that this opioid should not be used not only in patients with renal failure, but also in those with normal renal function and acute or chronic pain. In addition to having no advantage over other opioids, it easily induces addiction. Toxicity risk is high. Meperidine is dialyzable, but it is unsafe for dialytic CRF patients ${ }^{26}$

\section{Fentanyl}

This is a synthetic liposoluble opioid, approximately 80 times more potent than morphine. In addition to solution for intravenous or neuraxial use, it became popular due to its transdermal presentation, which reaches balance with plasma in approximately $12 \mathrm{~h}$ after its application, with continuous release of the drug for $72 \mathrm{~h}$. It is adequate to treat pain in patients with stable opioid doses ${ }^{34}$.

Some countries have the oral transmucosal solution which provides fast absorption and is useful to treat incidental pain $^{34}$.

Fentanyl is metabolized in the liver, with formation of inactive metabolites ${ }^{31}$. It does not form active metabolites ${ }^{26}$. Since a minor percentage of the drug is excreted unaltered by the urine, this is a safe drug for renal failure patients ${ }^{42}$. Due to its high molecular weight, high protein binding, low hydrosolubility and high distribution volume, the drug is not easily dialyzable ${ }^{43}$. It is not dialyzable but is safe for dialytic CRF patients ${ }^{26}$.

Recommended dose for patients with GFR above $50 \mathrm{~mL} / \mathrm{min}$ is $100 \%$; for GFR between 10 and $50 \mathrm{~mL} / \mathrm{min}$ is $75 \%$ and for GFR below $10 \mathrm{~mL} / \mathrm{min}$ it is $50 \%{ }^{40}$

\section{Methadone}

This is a synthetic opioid 5-10 times more potent than morphine. In addition to action on opioid receptors, it has antagonist effects on $\mathrm{N}$-methyl-D-aspartate (NMDA) receptors ${ }^{34}$. It is sold as racemic mixture where the isomer L-methadone acts on $\mu$ opioid receptors, while D-methadone acts on NMDA receptors. Due to its pharmacodynamics, it is useful to treat nociceptive and neuropathic pains $s^{44}$. 
In spite of its liposolubility, it has high bioavailability after oral administration. It is extensively bound to acid alpha1-glucoprotein, with broad tissue distribution, responsible for build up and long elimination half-life during chronic treatment with this opioid ${ }^{34}$.

It is metabolized in the liver and intestines, resulting in inactive metabolites, being most part eliminated by the bile. It does not form active metabolites ${ }^{26}$. So, even not being cleared by hemodialysis, it is safe for renal failure patients ${ }^{45}$. However, there is the need for frequent evaluation with dose and interval adjustments because it is a long-lasting drug.

Recommended dose for patients with GFR above $50 \mathrm{~mL} / \mathrm{min}$ is $100 \%$; for GFR between 10 and $50 \mathrm{~mL} / \mathrm{min}$ it is $100 \%$ and for GFR below $10 \mathrm{~mL} / \mathrm{min}$ it is $50-75 \%{ }^{40}$. It is not dialyzable but is safe for dialytic CRF patients ${ }^{26}$.

\section{ANTICONVULSANTS}

\section{Gabapentine}

This is an anticonvulsant primarily used to treat neuropathic pain, with well tolerated adverse effects. It was synthesized as analog of gamma-aminobutyric acid (GABA), but does not significantly interact with this or other neurotransmitters. Its action mechanism is through the binding to alpha-2-delta subunits of voltage-dependent calcium channels, decreasing calcium entrance in nervous terminations and the release of excitatory neurotransmitters ${ }^{46}$.

It is excreted unaltered by the urine being the elimination dependent on GFR. Approximately $35 \%$ of the drug are cleared during hemodialysis. This drug needs dose adjustment according to GFR estimates when administered to patients with renal failure ${ }^{47}$.

If GFR is equal to or above $80 \mathrm{~mL} / \mathrm{min}^{-1}$ maximum daily dose may be 900 to $3600 \mathrm{mg}$; if GFR 50 to 79 , from 600 to $1800 \mathrm{mg}$; if GFR between 30 and 49, 300-900mg; if GFR between 15 and 29,150 to $600 \mathrm{mg}$ and if GFR below 15,150 to $300 \mathrm{mg}^{48}$.

\section{Pregabalin}

As gabapentin, pregabalin is a structural GABA analog without GABAergic activity and acts on calcium channels alpha2-delta receptors. It is rapidly absorbed after oral administration, with bioavailability above $90 \%$, and maximum plasma concentration reached one hour after its ingestion ${ }^{49}$.

It suffers little metabolism in humans (less than $2 \%$ ), being excreted unaltered by the urine. So, it does not interact with liver enzymatic system, having little pharmacological interaction. However, there is the need for dose adjustment for patients with GFR below $60 \mathrm{~mL} / \mathrm{min}^{-1} 50$.

If GFR is equal to or above $60 \mathrm{~mL} \cdot \mathrm{min}^{-1}$ maximum daily dose may be $600 \mathrm{mg}$; if GFR between 30 and 59, of $300 \mathrm{mg}$; if GFR between 15 and 29, 150mg; and if GFR below 15, 75 mg ${ }^{51}$.

\section{Carbamazepine}

This is an anticonvulsant with anticholinergic, antidepressant, antiarrhythmic actions, in addition to inhibiting neuromuscular transmission. It induces increase of antidiuretic hormone release. Its action mechanism is through the inhibition of sodium channels, suppressing spontaneous activity of A-delta and C fibers and decreasing glutamate release in nervous terminations $s^{46}$.

Used since the 1960s, it is still considered a first line drug to treat trigeminal neuralgia ${ }^{52}$. However, its clinical use requires attention, due to pharmacological interactions and adverse effects on the central nervous system ${ }^{53}$. It has high bioavailability after oral administration. There is $72 \%$ renal excretion, being $3 \%$ unaltered. Since a small portion of the original compound is excreted by the urine, there will be no pharmacokinetic alteration in patients with impaired renal function ${ }^{46}$.

\section{Oxcarbazepine}

In spite of structural similarities with carbamazepine and of same clinical indications, oxcarbazepine has major pharmacokinetic differences ${ }^{46}$. As opposed to carbamazepine, it does not induce cytochrome $\mathrm{P} 450$, which significantly decreases its interaction with other substances ${ }^{54}$.

Its clinical effect is due to voltage-dependent sodium channels block, in addition to modulating calcium channels types $\mathrm{N}$ and $\mathrm{P}^{46}$.

There is $95 \%$ absorption of the dose by the gastrointestinal tract. Less than $1 \%$ of the dose is eliminated unaltered by the urine 9 . However, in patients with renal failure, dose should be cut in half, due to significant plasma level increase of its derivative mono-hydroxi, its primary metabolite ${ }^{54}$.

Similarly to carbamazepine, there is possibility, higher with oxcarbazepine, of dermatological reactions and hyponatremia during treatment with this anticonvulsant ${ }^{46}$.

\section{ANTIDEPRESSANTS}

\section{Tricyclic antidepressants}

Tricyclics are considered first line drugs to treat neuropathic pain $^{55}$. Tertiary amines, such as amitriptyline, are potent norepinephrine and serotonin reuptake inhibitors, whereas secondary amines, such as nortriptyline, act predominantly on norepinephrine reuptake ${ }^{56}$.

Amitriptyline bioavailability is low after oral administration. Its elimination is primarily renal, during several days, and the drug is not dialyzable due to its strong binding to plasma proteins $^{55}$. However, there is no need for dose adjustment in renal failure ${ }^{57}$. Common amitriptyline adverse effects are poorly tolerated by renal failure patients. Among them, there are dry mouth, cardiac conduction abnormalities, weight gain, sedation and orthostatic hypotension.

Nortriptyline is an active amitriptyline metabolite. It suffers extensive first liver passage effect, with formation of active metabolites. It causes less anticholinergic and cardiovascular effects than its original compound, being better tolerated ${ }^{55}$. There is no need for dose adjustment in renal failure ${ }^{57}$.

Venlafaxine forms an active metabolite (O-demethylvenlafaxine $)^{58,59}$ and approximately $87 \%$ of the administered dose are excreted by the urine in the first $48 \mathrm{~h}$, being $5 \%$ as venlafaxine, $26 \%$ as O-demethylvenlafaxine and $27 \%$ as inactive 
metabolites. Its elimination half-life is similar to fluoxetine (3 to 5 days), but in renal failure there is $50-180 \%$ increase $^{60,61}$. Duloxetine forms active metabolites which are mostly excreted unaltered by the urine and in less quantity by feces ${ }^{62,63}$. Duloxetine should be avoided in patients with creatinine clearance below $30 \mathrm{~mL} / \mathrm{min}^{62}$.

\section{CONCLUSION}

The use of analgesics in patients with renal failure is a challenge. Adequate treatment should take into consideration pain intensity and duration and pharmacokinetic changes caused by renal disease. Matching drugs to patients' clinical conditions may provide satisfactory analgesia with minor adverse effects and without deterioration of underlying clinical conditions.

\section{REFERENCES}

1. Coresh J, Byrd-Holt D, Astor BC, Briggs JP, Eggers PW, Lacher DA, et al. Chronic kidney disease awareness, prevalence, and trends among U.S. adults, 1999 to 2000. J Am Soc Nephrol. 2005;16(1):180-8.

2. Davison SN. Pain in hemodialysis patients: prevalence, cause, severity, and management. Am J Kidney Dis. 2003;42(6):1239-47.

3. Weisbord SD, Fried LF, Arnold RM, Fine MJ, Levenson DJ, Peterson RA, et al. Prevalence, severity, and importance of physical and emotional symptoms in chronic hemodialysis patients. J Am Soc Nephrol. 2005;16(8):2487-94.

4. Stewart AL, Hays RD, Ware JE Jr. The MOS short-form general health survey. Reliability and validity in a patient population. Med Care. 1988;26(7):724-35.

5. Meyer KB, Espindle DM, DeGiacomo JM, Jenuleson CS, Kurtin OS, Davies AR. Monitoring dialysis patients' health status. Am J Kidney Dis. 1994;24(2):267-79.

6. Merkus MP, Jager KJ, Dekker FW, De Haan RJ, Boeschoten EW, Krediet RT. Quality of life over time in dialysis: the Netherlands Cooperative Study on the Adequacy of Dialysis. NECOSAD Study Group. Kidney Int. 1999;56(2):720-8.

7. Diaz-Buxo JA, Lowrie EG, Lew NL, Zhang H, Lazarus JM. Quality-of-life evaluation using the Short Form 36: comparison in hemodialysis and peritoneal dialysis patients. Am J Kidney Dis 2000;35(2):293-300.

8. Williams A, Manias E. Pain management in hospitalized patients with chronic kidney disease and comorbidities. Ren Soc Aust J. 2007;3(3)76-83.

9. Issy AM, Sakata RK. Anti-inflamatórios. In: Sakata RK, Issy AM, (editores). Fármacos para tratamento da dor. $1^{\mathrm{a}}$ ed. Barueri, SP: Manole; 2008. 1-44p.

10. Schug SA. Clinical pharmacology of non-opioid and opioid analgesics. Pain - An Updated Review: Refresher Course Syllabus. Seattle: IASP Press; 2005. 31-40p.

11. Kurella M, Bennett WM, Chertow GM. Analgesia in patients with ESRD: a review of available evidence. Am J Kidney Dis. 2003;42(2):217-28.

12. Whelton A. Nephrotoxicity of nonsteroidal anti-inflammatory drugs: physiologic foundations and clinical implications. Am J Med. 1999;106(5B):13S-24S.

13. Pope JE, Anderson JJ, Felson DT. A meta-analysis of the effects of nonsteroidal anti-inflammatory drugs on blood pressure. Arch Intern Med. 1993;153(4):477-84.

14. Tan SY, Shapiro R, Kish MA. Reversible acute renal failure induced by indomethacin. JAMA. 1979;241(25):2732-3.

15. Carmichael J, Shankel SW. Effects of nonsteroidal anti-inflammatory drugs on prostaglandins and renal function. Am J Med. 1985;78(6Pt1):992-1000.

16. Diener H. Leczenie bólu. Zespoly bólowe - metody postepowania. Urban \& Partner, Wroclaw, 2005. 294-6p

17. Rezende RM, Franca DS, Menezes GB, dos Reis WG, Bakhle YS, Francischi JN. Different mechanisms underlie the analgesic actions of paracetamol and dipyrone in a rat model of inflammatory pain. Br J Pharmacol. 2008;153(4):760-8.

18. Lorenzetti BB, Ferreira SH. Mode of analgesic action of dipyrone: direct antagonism of inflammatory hyperalgesia. Eur J Pharmacol. 1985;114(3):375-81

19. Hinz B, Cheremina O, Buchmakov J, Renner B, Zolk O, Fromm MF, et al. Dipyrone elicits substantial inhibition of peripheral cyclooxygenases in humans: new insights into the pharmacology of an old analgesic; FASEB J. 2007;21(10):2343-51.

20. Graham GG, Scott KF. Mechanism of action of paracetamol. Am J Ther. 2005;12(1):46-55.

21. Chun LJ, Tong MJ, Busuttil RW, Hiatt JR. Acetaminophen hepatotoxicity and acute liver failure. J Clin Gastroenterol. 2009;43(4):342-9.

22. Mazer M, Perrone J. Acetaminophen-induced nephrotoxicity: pathophysiology, clinical manifestations and management. J Med Toxicol. 2008;4(1):2-6.

23. Henrich WL, Agodoa LE, Barrett B, Bennett WM, Blantz RC, Buckalew VM Jr, et al. Analgesics and the kidney: summary and recommendations to the Scientific Advisory Board of the National Kidney Foundation from an Ad Hoc Committee of the National Kidney Foundation. Am J Kidney Dis. 1996;27(1):162-5.
24. Rhee C, Broadbent A. Palliation and liver failure: palliative medications dosage guidelines. J Palliat Care. 2007;10(3):677-85.

25. Lee CR, McTavish D, Sorkin EM. Tramadol. A preliminary review of its pharmacodynamic and pharmacokinetic properties, and therapeutic potential in acute and chronic pain states. Drugs. 1993;46(2):313-40.

26. King S, Forbes K, Hanks GW, Ferro CJ, Chambers EJ. A systematic review of the use of opioid medication for those with moderate to severe cancer pain and renal impairment: a European Palliative Care Research Collaborative opioid guidelines project. Palliat Med. 2011;25(5):525-52.

27. Boyer EW, Shannon M. The serotonin syndrome. N Engl J Med. 2005;352(11):112-20.

28. Izzedine H, Launay-Vacher V, Abbara C, Aymard G, Bassilios N, Deray G. Pharmacokinetics of tramadol in a hemodialysis patient. Nephron. 2002;92(3):755-6.

29. Verwey-van Wissen CP, Koopman-Kimenai PM, Vree TB. Direct determination of codeine, norcodeine, morphine and normorphine with their corresponding O-glucuronide conjugates by high performance liquid chromatography with electrochemical detection. J Chromatogr 1991;570(2):309-20.

30. Vree TB, van Dongen RT, Koopman-Kimenai PM. Codeine analgesia is due to codeine-6-glucuronide, not morphine. Int J Clin Pract. 2000;54(6):395-8.

31. Murtagh FE, Chai MO, Donohoe P, Edmonds PM, Higginson IJ. The use of opioid analgesia in end-stage renal disease patients managed without dialysis: recommendations for practice. J Pain Palliat Care Pharmacother. 2007;21(2):5-16.

32. Benyamin R, Trescot AM, Datta S, Buenaventura R, Adlaka R, Sehgal N, et al. Opioid complications and side effects. Pain Physician, 2008;11(2 Suppl):S105-20.

33. Guay DR, Awni WM, Findlay JW, Halstenson CE, Abraham PA, Opsahl JA, et al. Pharmacokinetics and pharmacodynamics of codeine in end-stage renal disease. Clin Pharmacol Ther. 1988;43(1):63-71.

34. Niscola P, Scaramucci L, Vischini G, Giovannini M, Ferrannini M, Massa P, et al The use of major analgesics in patients with renal dysfunction. Curr Drug Targets. 2010;11(6):752-8

35. Lalovic B, Kharasch E, Hoffer C, Risler L, Liu-Chen LY, Shen DD. Pharmacokinetics and pharmacodynamics of oral oxycodone in healthy human subjects: role of circulating active metabolites. Clin Pharmacol Ther. 2006;79(5):461-79.

36. Foral PA, Ineck JR, Nystrom KK. Oxycodone accumulation in a hemodialysis patient. South Med J. 2007;100(2):212-4.

37. Gong QL, Hedner T, Hedner J, Björkman R, Nordberg G. Antinociceptive and ventilatory effects of the morphine metabolites: morphine-6-glucuronide and morphine-3-glucuronide. Eur J Pharmacol. 1991;193(1):47-56.

38. Angst MS, Buhrer M, Lotsch J. Insidious intoxication after morphine treatment in renal failure: delayed onset of morphine-6-glucuronide action. Anesthesiology. 2000;92(5):1473-6.

39. Mercadante S, Arcuri E. Opioids and renal function. J Pain. 2004;5(1):2-19.

40. Aronoff GR, Bennett WM, Berns JS, et al. Drug prescribing in renal failure: dosing guidelines for adults and children. $5^{\text {th }}$ ed. Philadelphia, PA: American College of Physicians; 2007. 18-9p.

41. O'Connor AB, Lang VJ, Quill TE. Eliminating analgesic meperidine use with a supported formulary restriction. Am J Med. 2005;118(8):885-9.

42. Cockcroft DW, Gault MH. Prediction of creatinine clearance from serum creatinine. Nephron. 1976;16(1):31-41.

43. Dean M. Opioids in renal failure and dialysis patients. J Pain Symptom Manage. 2004;28(5):497-504

44. Lugo RA, Satterfield KL, Kern SE. Pharmacokinetics of methadone. J Pain Palliat Care Pharmacother 2005;19(4):13-24.

45. Furlan V, Hafi A, Dessalles MC, Bouchez J, Charpentier B, Taburet AM. Methadone is poorly removed by haemodialysis. Nephrol Dial Transplant. 1999;14(1):254-5.

46. Menezes MS, Sakata RK, Issy AM. Anticonvulsivantes. In: Sakata RK, Issy AM. (etiroes). Fármacos para tratamento da dor. 1ª ed. Barueri, SP: Manole; 2008. 111-38p.

47. Blum RA, Comstock TJ, Sica DA, Schultz RW, Keller E, Reetze P, et al. Pharmacokinetics of gabapentin in subjects with various degrees of renal function. Clin Pharmacol Ther. 1994;56(2):154-9.

48. Israni RK, Kasbekar N, Haynes K, Berns JS. Use of antiepileptic drugs in patients with kidney disease. Semin Dial. 2006;19(5):408-16.

49. Ben-Menachem E. Pregabalin pharmacology and its relevance to clinical practice. Epilepsia. 2004;45(Suppl 6):13-8.

50. Kugler AR, Robbins JL, Strand JC, et al. Pregabalin overview: a novel CNS-active compound with anticonvulsant activity. Poster presented at the Annual Meeting of the American Epilepsy Society, Seattle: Washington; 2002. 6-11p.

51. Diaz A, Deliz B, Benbadis SR. The use of newer antiepileptic drugs in patients with renal failure. Expert Rev Neurother. 2012;12(1):99-105.

52. Killian JM, Fromm GH. Carbamazepine in the treatment of neuralgia. Use of side effects. Arch Neurol. 1968;19(2):129-36.

53. Markman JD, Dworkin RH. Ion channel targets and treatment efficacy in neuropathic pain. J Pain. 2006;7(1):538-47

54. Grant SM, Faulds D. Oxcarbazepine: A review of its pharmacology and therapeutic potencial in epilepsy, trigeminal neuralgia and affective disorders. Drugs. 1992;43(6):873-88.

55. Gazi MC, Sakata RK, Issy AM. Antidepressivos. In: Sakata RK, Issy AM, (editores). Fármacos para tratamento da dor. $1^{\text {a }}$ ed. Barueri, SP: Manole; 2008. 81-110p.

56. Baldessarini RJ. Drug therapy of depression and anxiety disorders. In: Brunton LL, Lazo JS, Parker KL, (editors). Goodman and Gilman's the pharmacological basis of therapeutics, New York: McGraw Hill; 2006. 452-4p. 
57. Nagler EV, Webster AC, Vanholder R, Zoccali C. Antidepressants for depression in stage 3-5 chronic kidney disease: a systematic review of pharmacokinetics, efficacy and safety with recommendations by European Renal Best Practice (ERBP). Nephrol Dial Transplant. 2012;27(10):3736-45.

58. Morton WA, Sonne SC, Verga MA. Venlafaxine: a structurally unique and novel antidepressant. Ann Pharmacother. 1995;29(4):387-95.

59. Kalso E. Pharmacological Management of Pain: Anticonvulsants, Antidepressants, and Adjuvant Analgesics. Pain - An Updated Review: Refresher Course Syllabus, IASP Press, Seatle; 2005. 19-29p.

60. Troy SM, Parker VD, Fruncillo RJ, Chiang ST. The pharmacokinetics of venlafaxine when given in a twice-daily regimen. J Clin Pharmacol. 1995;35(4):404-9.

61. Troy SM, Parker VP, Hicks DR, Pollack GM, Chiang ST. Pharmacokinetics and effect of food on the bioavailability of orally administered venlafaxine. J Clin Pharmacol. 1997;37(10):954-61

62. Westanmo AD, Gayken J, Haight R. Duloxetine: a balanced and selective norepinephrine- and serotonin-reuptake inhibitor. Am J Health Syst Pharm. 2005;62(23):2481-90.

63. Lantz RJ, Gillespie TA, Rash TJ, Kuo F, Skinner M, Kuan HY, et al. Metabolism, excretion, and pharmacokinetics of duloxetine in healthy human subjects. Drug Metab Dispos. 2003;31(9):1142-50. 